УДК 342.25

DOI: https://doi.org/10.26642/jen-2020-3(93)-57-62

Г.І. Жекало, к.політ.н., доц.

А.В. Ключенко, к.е.н., доц.

Івано-Франківський навчально-науковий інститут менеджменту ТНЕУ

\title{
Програми інформатизації як складова механізму впровадження електронного урядування: порівняльна характеристика міст
}

\begin{abstract}
Ключовою складовою розвитку в системі публічного управління сьогодні є впровадження елементів електронного урядування на всіх етапах взаємодії владних структур з громадськістю. Одним із головних елементів електронного уряду є широка інформатизація суспільного життя, адже інформаційний ресурс у сфері муніџипального управління не мени важливий, ніж матеріальні, трудові, енергетичні, фінансові або інші ресурси. Тому головною метою статті $\epsilon$ саме порівняльна характеристика програми інформування громадськості на місцевому рівні. Ми з'ясували, щзо головним методом інформування громадськості та забезпечення комунікаціі владних структур і населення є функиіонування офіційних вебсайтів. Ми думаємо, щуо для визначення рівня відкритості та прозорості роботи того чи іншого органу влади найважливішими показниками є такі, як інформаційний контент інтернет-сайту, наявність елементів управління, можливість зворотного зв'язку, інтерактивність, доступність інформаціі різними мовами, наявність почукових елементів сайтів, чітке групування повідомлень («хештегування»), відображення актуальної інформації не тільки на сайтах, але й на офіційних сторінках у соиіальних мережах. У результаті дослідження ми зробили висновок, щу вебсайти $\epsilon$ офічійним джерелом інформування громадськості про минулі і майбутні події міста, дії влади міста, їх плани $і$ перспективи. Водночас саме вебсайт є основним джерелом, який може забезпечити участь громадян у життєдіяльності міста. Сучасні версї офіиійних сайтів міст спрямовані не тільки на інформування, а й на комунікацію з громадськістю, можливість отримання відповідей, коментарів, зауважень і пропозицій, враховуючи при цьвому фізіологічні характеристики, особливості національності тощзо.
\end{abstract}

Ключові слова: електронне урядування; інформатизація; інформаційне суспільство; вебсайт; сочіальні мережі.

Актуальність теми. Після суспільно-політичних подій кінця 2013 - початку 2014 року, зміни владних структур та трансформації вектора політичного розвитку Уряд України активно проводить низку реформ, які спрямовують країну шляхом європейської інтеграції до відкритої та прозорої демократії. Серед головних пріоритетів реформи як факторів перспективної євроінтеграції України є децентралізація, боротьба з корупцією, відкриті принципи державного управління, прозорість, підзвітність і ефективність влади. Серед них активне впровадження електронного урядування як інструменту досягнення всіх попередніх пріоритетів та як окремої системи взаємодії влади й громадськості на засадах відкритості, часової та просторової незалежності.

На сьогодні цей напрям діяльності став одним із пріоритетних у роботі уряду і беззаперечно це позитивний аспект, який сприяє підвищенню рівня як самої держави, так і окремої сфери публічного адміністрування. Однак малодослідженість та недостатня наукова обгрунтованість концептуальної основи системи та складових е-урядування може відобразитися на ефективності реалізації реформи. Тому це зумовлює актуальність дослідження цієї проблематики.

Аналіз останніх досліджень та публікацій з визначеної проблематики. Найбільш вагомим в Україні дослідженням, що докладно описує суть, складові, особливості, основи та стратегії реалізації електронного урядування та електронної демократії, є навчальний посібник у 15 томах «Електронне урядування та електронна демократія» за загальною редакцією А.І. Семенченка та В.М. Дрешпака. Проблеми і перспективи розвитку електронного урядування в Україні у своїх дослідженнях розкрили: Ю.Приймак, Л.Левченко, В.Дрешпак, В.Сганов, Ю.Добуш, А.Грицан, М.Климаш, Я.Калакура та інші. Зарубіжний досвід упровадження електронного урядування у публічному управлінні аналізували такі науковці, як О.Мазур, А.Ушаков, О.Онуфрієнко, А.Серенок та інші. Впровадження інструментів електронного урядування на регіональному рівні у своїх дослідженнях вивчали: А.Серенюк, О.Бузулук, В.Марченко, В.Коновал. Аналіз матеріалів цих науковців став теоретичною основою для написання статті. Базою дослідження $є$ також нормативно-правові документи, положення, акти, які є основою впровадження системи електронного урядування в Україні. Для проведення дослідження використали також офіційні вебсайти регіональних органів влади.

Метою статті є аналіз програм інформатизації як складової механізму впровадження електронного урядування на прикладі оформлення та функціонування офіційних вебсайтів міст. 
Викладення основного матеріалу. У контексті вивчення е-урядування можна розглядати три складові, зокрема, електронне адміністрування (e-administration), електронну взаємодію з громадянами (еcitizens and e-services) та інформаційне суспільство (e-society).

Електронне адміністрування у найбільш загальному вигляді можна описати як заміну в організації паперових процесів на електронні процеси. Це інструмент ІКТ, метою якого є підвищення продуктивності роботи організації і може охоплювати як внутрішні, так і зовнішні комунікації для будь-якої організації. Електронна взаємодія з громадськістю передбачає можливість отримувати необхідні послуги не виходячи 3 дому, а уряд зможе пропонувати та надавати актуальні для населення послуги за допомогою інтернетзасобів.

Інформаційне суспільство (e-society) у найбільш загальному розумінні визначається як тип суспільства, де широко використовуються інформаційні та комунікаційні технології для досягнення спільних інтересів та цілей основними соціально зацікавленими сторонами (тобто громадянами, бізнесом, урядом тощо). Вважаємо, що під час визначення е-society як складової е-урядування акцентується увага саме на можливості доступу громадян до інформації, широкій інформатизації суспільства усіма можливими засобами та інструментами, залученні населення до використання сучасних IКТ та рівня його інформаційно-технологічної компетентності. Водночас саме цим терміном можна описати активне виробництво, використання та споживання інформації населенням. Інформаційне суспільство $\epsilon$ найважливішим фактором та інструментом інформаційної та комунікаційної взаємодії.

Об’єктом для аналізу та порівняння практики інформатизації як складової електронного урядування ми обрали 5 найбільших міст Західної України, обласні адміністративні центри: Івано-Франківськ, Чернівці, Львів, Тернопіль, Ужгород.

Відповідно до Рейтингу прозорості 100 найбільших міст України за 2019 рік [11], запропонованого компанією Transparency International, досліджувані міста займають такі позиції: Івано-Франківськ на 17 місці з показником 61,6; Чернівці - на 28 місці з показником 55,8; Львів - на 6 місці 3 показником 73,7; Тернопіль - на 3 місці з показником 76,0 і Ужгород - на 23 місці з показником 56,6 (найбільша кількість балів, яку може отримати місто - 100). Експерти брали до уваги відкритість міських рад за різними показниками (86 індикаторів) у 14 сферах. Серед них пріоритетними в аналізі були відкритість необхідної для громадян інформації та надання їм реальних інструментів впливу й участі.

Оцінка і порівняння різних практик - це основні інструменти визначення статусу існуючого електронного уряду, контролю досягнення цілей, підтвердження ефективності застосовних політик, виявлення переваг і недоліків, розробки нових заходів та пошуки нових ефективних моделей управління. Відповідно, першочергово потрібно проаналізувати рівень інформатизації населення з боку владних інституцій. Варто зауважити, що інформаційний ресурс у сфері муніципального управління не менш важливий, ніж матеріальні, трудові, енергетичні, фінансові та інші ресурси.

Законом України «Про доступ до публічної інформації» [3] передбачено, що розпорядники інформації, тобто «суб’ єкти владних повноважень - органи державної влади, інші державні органи, органи місцевого самоврядування, органи влади Автономної Республіки Крим, інші суб'єкти, що здійснюють владні управлінські функції відповідно до законодавства та рішення яких є обов'язковими для виконання» зобов'язані оприлюднювати та надавати достовірну, точну, перевірену суспільно важливу інформацію, що стосується всіх аспектів їх роботи, використовуючи різні форми та засоби.

Інформаційне забезпечення системи управління муніципальним органом влади - це взаємопов'язана сукупність необхідної інформації, форм і способів їі подання та організації у просторі і часі, що забезпечує рішення необхідних завдань у системі управління.

Особливо важливий поділ інформації на внутрішню (щодо органу місцевого самоврядування) i зовнішню. До внутрішньої належать рішення представницького органу муніципальної освіти, постанови та розпорядження голови адміністрації та його заступників, протоколи засідань колегії, відомості обліку виданих муніципальних правових актів, звіти про роботу структурних підрозділів адміністрації, довідки про стан розгляду звернень громадян тощо. Подібна інформація дає можливість більш повно презентувати фактичний стан справ в адміністрації, раціонально розподіляти сили і робочий час, ефективно організовувати роботу.

Зовнішня інформація щодо функціонування муніципальних органів влади може здійснюватися різними способами, зокрема, через засоби масової інформації, інформаційні запити, офіційні вебсайти, офіційні сторінки тощо.

Одним із засобів інформаційної діяльності та комунікації органів місцевої влади з громадськістю є офіційний вебсайт. Якщо ще десяток років тому наявність офіційного сайту публічної структури, фізичної чи юридичної особи була рідкістю, інформація оновлювалася дуже рідко, то сьогодні майже кожна державна структура має власний офіційний сайт, який оновлюється щоденно, публікуються останні новин та важливі оголошення. Окрім того, робота всіх органів влади як національних, так і регіональних на сьогодні об'єднана в єдиний інформаційний вебпортал. Саме вебсайт є своєрідною об'єднувальною ланкою між органом влади та населенням, інформатором для громадян щодо діяльності органу влади. 
Наявність вебсторінки допомагає зекономити час як для тих, хто надає інформацію, так і для тих, хто іiі отримує, сприяє масовому охопленню важливих даних та підтримує спрощений спосіб надання послуг, а також забезпечує відкритий і прозорий спосіб діяльності органу публічної влади.

Вітчизняні науковці застосовують різноманітні критерії для моніторингу і порівняння вебсайтів органів влади. Значна частина дослідників орієнтується на таких ознаках, як інформаційне оновлення та інформативність сайту, технічні характеристики, інтерактивні можливості, доступність інформації на різних мовах, складність у користуванні сайтом та інші. Цікавим є підхід для аналізу сайту, що запропонований науковцями Т.Біловою, І.Побіженком, В.Дьоміною, які зазначають, що моніторинг вебсайтів доцільно проводити за такою моделлю: $\mathrm{F}=\{\mathrm{a}, \mathrm{b}, \mathrm{c}, \mathrm{d}, \mathrm{e}, \mathrm{f}\}$, де $\mathrm{F}$ - показник сайту, який залежить від: a - інтерфейсу; b - зручності у користуванні; c - клієнтоорієнтованості; d - визначення пріоритетних потреб користувачів; е - компактності подання інформації [1].

На нашу думку, для визначення рівня відкритості і прозорості роботи того чи іншого органу влади важливою складовою є інформаційний контент інтернет-сайту. Інформаційна наповнюваність вебсайту органу влади має містити інформацію про статутну, організаційну, фінансову особливості роботи організації, інформацію про можливість зворотного зв'язку громадян та державної структури, інформацію щодо можливостей залучення громадян до ухвалення рішень та до безпосередньої роботи органу, про види і типи інформації, якими володіє орган влади і форми, в яких ця інформація зберігається, про зміст будьяких адміністративних чи політичних рішень, що впливають на суспільство.

Склад, структура та оформлення інформації, яка надається органами виконавчої влади на власних вебсайтах визначаються вимогами постанови Кабінету Міністрів України від 04.01.2002 (3 останньою редакцією 25 лютого 2020 року) «Про Порядок оприлюднення у мережі Інтернет інформації про діяльність органів виконавчої влади» [9], наказом «Про затвердження Порядку інформаційного наповнення та технічного забезпечення Єдиного веб-порталу органів виконавчої влади та Порядку функціонування вебсайтів органів виконавчої влади» [3], Постановою Кабінету Міністрів України від 12 червня 2019 року «Про внесення змін до деяких постанов Кабінету Міністрів України щодо функціонування офіційних вебсайтів органів виконавчої влади» [10].

Повертаючись до аналізу, необхідно зазначити, що сайти досліджуваних міст відповідають основним вимогам, що зазначені у цих документах. Офіційна хроніка та новини публікуються переважно щодня або через день. Анонси подій, зустрічей, візитів, акцій тощо публікуються переважно у той же день або 1-2 дні перед заходом, однак документально дозволено не пізніше ніж за 2 дні та у надзвичайних випадках - не пізніше ніж за 1 годину до початку заходу. Пресрелізи про заходи та різноманітні події опубліковуються не пізніше ніж через добу після події. Однак досить часто офіційні повідомлення, наприклад, передаються через регіональні ЗМІ чи соцмережі і не публікуються на сайтах. Інтерв'ю та виступи чиновників не пізніше 3 днів після події. Статистичні та аналітичні матеріали періодично.

Порядок функціонування вебсайтів органів виконавчої влади передбачає також «обов'язкову наявність елементів управління, які надають можливість користувачу змінити розмір шрифту, кольоровий контраст, розміщуються на початку кожної вебсторінки альтернативної версії офіційного вебсайту органу виконавчої влади, а за їі відсутності - на початку кожної вебсторінки основної версії [3]. Тобто це можливість доступу до розміщеної інформації користувачам з порушеннями зору та слуху. Відповідно, вебсайт міста Івано-Франківськ містить версію для слабозрячих, сайти Тернопільської та Чернівецької міських рад станом на березень 2020 року не мають версій для людей з обмеженими можливостями. Показовим є сайт Ужгородської міської ради, де користувачі мають право регулювати розмір шрифту, колір сайту, зображення. Окрім того, громадяни 3 обмеженими слуховими можливостями можуть звертатися до органів виконавчої влади мовою жестів через програму Skype. Версія сайту Львівської міської ради також адаптована для незрячих користувачів, оскільки «за допомогою програмного забезпечення, програм невізуального доступу до робочого столу комп'ютера, які працюють за рахунок мовного сповіщення користувача про об'єкти на робочому столі і вікнах, діях і процесах, користувач може переглядати сайт Львівської міської ради без будь-яких перешкод» [5]. На сайті надано перелік програм, які допоможуть у користуванні сайтом.

Однією зі складових інформаційної діяльності органів місцевої виконавчої влади є відображення актуальної інформації не тільки на вебсайтах, а й на офіційних сторінках у соціальних мережах. Соціальні мережі відіграють надзвичайно вагому роль у суспільному житті населення, адже є частиною «нових медіа», що дозволяють аудиторії не тільки отримувати інформацію, а й реагувати на неї, давати відповідь, уточнювати та інше. Найбільш популярними в Україні є такі соціальні мережі, як «Facebook», «Twitter», «Instagram», «You tube». У соціальних мережах створюють офіційні сторінки органи влади, посадові особи. Із переліку вивчених нами міст офіційні сторінки міської ради у соціальних мережах $є$ у кожного. Крім того, є офіційні сторінки міських голів, де також публікуються останні новини міста, анонси, оголошення. Відповідно, вебсайт міста Івано-Франківськ містить на головній сторінці посилання на офіційні сторінки міської ради у таких соціальних мережах, як «Facebook», «Twitter»; Тернополя та 
Львова - «Facebook», «Twitter», «Instagram», «You tube»; Чернівців - «Facebook», «Twitter». Вебсайт міста Ужгород містить посилання на офіційну сторінку міської ради тільки в соціальній мережі «Facebook».

Офіційні сторінки у соціальних мережах ведуть також очільники досліджуваних міст. Інформація переважно перегукується із тією, що зазначена на офіційних вебпорталах. Вважаємо, що залучення нових сучасних форм комунікації - соціальних мереж - у роботу державних структур є позитивним аспектом. Перевагами такої форми висвітлення матеріалу для громадян є:

- $\quad$ можливість миттєвої відповіді на ту чи іншу інформацію публічних осіб або органу влади через функцію «коментар»;

- $\quad$ можливість обговорення кожної окремої новини чи події, дослідження реакції людей на ці події;

- можливість індивідуального віртуального звернення громадян до органу влади та очільника міста через особисте повідомлення;

- можливість публічних осіб чи органу влади проводити онлайн-трансляції, відео «наживо», що дозволяє громадянам бути віртуально «присутніми» на різноманітних заходах;

- $\quad$ структурованість інформації (поділ інформації за часом, виокремлення інформаційних дописів, відео, світлин, нотаток, подій, відгуків), доступна можливість прикріплення фото- та відеоматеріалів до текстової інформації;

- доступність поширення та перепоширення інформації, що збільшує охоплюваність 3 боку громадськості;

- збільшення залучення молоді до муніципального розвитку через публікації яскравих відео, світлин, оголошення молодіжних проєктів, подій, ініціатив, флешмобів тощо.

Показником якісного вебпорталу $є$ також офіційний переклад вебсторінок на іноземну мову, що дозволяє отримувати необхідну інформацію більшій групі людей і водночас підвищує рівень органу влади в очах іноземних партнерів. Адаптована інформація на іноземній мові відсутня на сайті Львівської та Чернівецької міських рад. Вебсайт Ужгородської міської ради містить тільки загальну інформацію про місцевий орган влади англійською мовою. Показовими $є$ вебсайти Тернопільської та Івано-Франківської міських рад, які надають доступний переклад публічної інформації англійською мовою.

Ще одним критерієм для аналізу вебсайтів, який свідчить про доступність інформації, змістовність, лаконічність та грамотність у використанні даних, є наявність пошукових елементів сайтів, чітке групування повідомлень («хештегування»). Такі функціональні характеристики сайту дозволяють отримувачам інформації знаходити необхідні дані значно швидше. Елемент для пошуку містить кожен сайт досліджуваних міських рад. Окрім того, новини на сайтах міських рад містять посилання на найбільш запитувані хештеги.

Зворотний зв'язок та комунікація з користувачем є ще одним вагомим критерієм для аналізу зручності сайту для громадськості. Можливість залишити відгуки та пропозиції щодо роботи сайту чи реакцію на певну подію, новину чи повідомлення свідчить про відкритість роботи міської влади, врахування побажань та інтересів читачів сайту. Елемент інтерактивності, тобто можливості направити лист, запитання чи коментар органу влади 3 сайту та одержати відповідь, $є$ важливою складовою комунікативності. Така можливість, на нашу думку, вказує на те, що вебсайт є «живим», діючим, зосередженим на громадськості.

На практиці інтерактивність сайту означає здатність підтримувати зв’язок між адміністрацією та відвідувачами у режимі реального часу без будь-яких допоміжних засобів, можливість зателефонувати за вказаним у контактних даних номером телефону, написати лист на e-mail або ж відправити факс прямо на сайті, здійснювати онлайн-консультації чи онлайн-чати.

У результаті аналізу вебсайтів місцевих органів влади як базових механізмів залучення громадськості до системи публічного управління було також виокремлено низку недоліків, які перешкоджають населенню повноцінно отримати право доступу до публічної інформації.

Серед недоліків інформаційного наповнення вебсайтів необхідно назвати зауваження, пов'язані 3 оприлюдненням не у повному обсязі інформації, обов'язковість розміщення якої регламентується нормативно-правовими актами. Також інформація часто може мати загальний характер без чіткої послідовності та поетапності дій, наприклад, для отримання тих чи інших послуг. Варто зазначити також факт розташування інформації не в логічних розділах, через що не забезпечується простота та зручність доступу до неї. Під час аналізу сайтів досліджуваних міст можна зауважити неуніфікованість форм сайтів, перелік різних рубрик, що часто може ускладнювати роботу.

Недоліком є те, що не вся інформація розміщується на альтернативних сторінках вебсайтів англомовній, російськомовній. Переважно англійською мовою публікується загальна інформація, натомість новини та важливі оголошення часто тільки на україномовній версії сайту. Це саме стосується елементів управління, які присутні не на всіх рубриках та сторінках. Також попри наявність пошукових систем на всіх сайтах місцевої влади, варто зауважити те, що інформація генерується не 3 усіх сторінок сайту (наприклад, пошук інформації здійснюється не по всьому вебсайту, а лише у розділі «Новини»). 
В умовах е-урядування окремі недоліки можна зауважити в системі надання адміністративних послуг, які відображені на вебсайтах. Зокрема, потребує розширення перелік електронних послуг, представлених на офіційному вебсайтів міста Ужгород, також удосконалення гіперпосилань, для безперервного переходу до отримання послуги онлайн прямо з сайту міста. Окрім того, у низці послуг нечітко наведений алгоритм отримання тої чи іншої послуги, а також обмежений доступ до отримання зразків чи бланків документів, які можуть отримати громадяни. Однак порівняльна характеристика публічних електронних послуг, які надають місцеві органи влади, - це тема для наших майбутніх досліджень.

Висновки та перспективи подальших досліджень. Підсумовуючи, зауважимо, що досліджувані нами офіційні сайти відповідають сучасним вимогам інформаційного розвитку держави, нормативноправовим засадам, ухвалених урядом та потребами й очікуваннями громадськості. У результаті аналізу досліджуваних вебсайтів було виявлено низку недоліків, зокрема, неуніфікованість форм сайтів, проблеми 3 інформаційним наповненням, доопрацювання сторінок сайтів на різних мовах, необхідність удосконалення інтерактивності сайту, пошукових систем. Потребує розширення перелік електронних адміністративних послуг, наведених на офіційних вебсайтах, та пряма можливість їх отримання із сайту. Незважаючи на це, вебсайти є офіційним джерелом інформування громадськості про минулі й майбутні події міста, дії влади міста, їх плани та перспективи. Водночас саме вебсайт $є$ основним джерелом, що може забезпечити участь громадян у життєдіяльності міста, оскільки містить актуальну інформацію про програми, проєкти, ініційовані владою та спрямовані на розвиток міста за співучасті його громадян. Крім того, сучасні версії офіційних сайтів міст спрямовані не тільки на інформування, а й комунікування 3 громадськістю. Відтак можна стверджувати, що саме активна робота місцевої влади над розвитком офіційного вебсайту є вагомою складовою інформатизації, комунікації i, водночас, впровадження ефективної програми електронного урядування.

\section{Список використаної літератури:}

1. Білова T. Порівняльний аналіз контенту сайтів органів державної влади / Т.Білова, О.Побіженко, О.Дьоміна [Електронний ресурс]. - Режим доступу : http://www.hups.mil.gov.ua/periodic-app/article/18988.

2. Про доступ до публічної інформації : Закон України / Відомості Верховної Ради України від 13 січня 2011 р. № 32 [Електронний ресурс]. - Режим доступу : https://zakon.rada.gov.ua/laws/show/2939-17\#Text.

3. Про затвердження Порядку інформаційного наповнення та технічного забезпечення Єдиного веб-порталу органів виконавчої влади та Порядку функціонування веб-сайтів органів виконавчої влади : наказ [Електронний ресурс]. - Режим доступу : https://zakon.rada.gov.ua/laws/show/z1021-02.

4. Офіційний сайт міста Івано-Франківськ [Електронний ресурс]. - Режим доступу : http://www.mvk.if.ua/.

5. Офіційний сайт Львівської міської ради [Електронний ресурс]. - Режим доступу : https://city-adm.lviv.ua/.

6. Офіційний сайт Тернопільської міської ради [Електронний ресурс]. - Режим доступу https://ternopilcity.gov.ua/.

7. Офіційний сайт міста Ужгород [Електронний ресурс]. - Режим доступу : https://rada-uzhgorod.gov.ua/.

8. Офіційний вебпортал Чернівецької міської ради [Електронний ресурс]. - Режим доступу http://chernivtsy.eu/portal/.

9. Про Порядок оприлюднення у мережі Інтернет інформації про діяльність органів виконавчої влади : Постанова Кабінету Міністрів України від 04.01.2002 р. [Електронний ресурс]. - Режим доступу : https://zakon.rada.gov.ua/laws/show/3-2002-\%D0\%BF.

10. Про внесення змін до деяких постанов Кабінету Міністрів України щодо функціонування офіційних вебсайтів органів виконавчої влади : Постанова Кабінету Міністрів України від 12 червня 2019 року № 493 [Електронний ресурс]. - Режим доступу : https://zakon.rada.gov.ua/laws/show/493-2019-\%D0\%BF.

11. Рейтинг прозорості 100 найбільших міст України. 2019 рік / Transparency International Ukraine, 2020 [Електронний ресурс]. - Режим доступу : https://decentralization.gov.ua/news/12152.

\section{References:}

1. Bilova, T., Pobizhenko, O. and D'omina, O., Porivnjal'nyj analiz kontentu sajtiv organiv derzhavnoi' vlady, [Online], available at: http://www.hups.mil.gov.ua/periodic-app/article/18988

2. Verhovna Rada Ukrai'ny (2011), Pro dostup do publichnoi' informacii', Zakon Ukrai'ny from 13 sichnja No. 32, [Online], available at: https://zakon.rada.gov.ua/laws/show/2939-17\#Text

3. Verhovna Rada Ukrai'ny, Pro zatverdzhennja Porjadku informacijnogo napovnennja ta tehnichnogo zabezpechennja Jedynogo veb-portalu organiv vykonavchoi' vlady ta Porjadku funkcionuvannja veb-sajtiv organiv vykonavchoi' vlady, nakaz, [Online], available at: https://zakon.rada.gov.ua/laws/show/z1021-02

4. Oficijnyj sajt mista Ivano-Frankivs'k, [Online], available at: http://www.mvk.if.ua/

5. Oficijnyj sajt L'vivs'koi' mis'koi' rady, [Online], available at: https://city-adm.lviv.ua/

6. Oficijnyj sajt Ternopil's'koi' mis'koi' rady, [Online], available at: https://ternopilcity.gov.ua/

7. Oficijnyj sajt mista Uzhgorod, [Online], available at: https://rada-uzhgorod.gov.ua/

8. Oficijnyj vebportal Chernivec'koi' mis'koi' rady, [Online], available at: http://chernivtsy.eu/portal/

9. Kabinet Ministriv Ukrai'ny (2002), Pro Porjadok opryljudnennja u merezhi Internet informacii' pro dijal'nist' organiv vykonavchoi' vlady, postanova vid 04.01, [Online], available at: https://zakon.rada.gov.ua/laws/show/3$2002-\% \mathrm{D} 0 \% \mathrm{BF}$ 
10. Kabinet Ministriv Ukrai'ny (2019), Pro vnesennja zmin do dejakyh postanov Kabinetu Ministriv Ukrai'ny shhodo funkcionuvannja oficijnyh veb-sajtiv organiv vykonavchoi' vlady, postanova vid 12 chervnja No. 493, [Online], available at: https://zakon.rada.gov.ua/laws/show/493-2019-\%D0\%BF

11. Transparency International Ukraine (2020), Rejtyng prozorosti 100 najbil'shyh mist Ukrai'ny. 2019 rik, [Online], available at: https://decentralization.gov.ua/news/12152

Жекало Ганна Іванівна - кандидат політичних наук, доцент кафедри міжнародної економіки, маркетингу i менеджменту Івано-Франківського навчально-наукового інституту менеджменту Тернопільського національного економічного університету.

Наукові інтереси:

- електронне урядування, методи та інструменти його ефективного впровадження;

- конфлікти та шляхи їх вирішення.

Ключенко Аделіна Вікторівна - кандидат економічних наук, доцент кафедри міжнародної економіки, маркетингу i менеджменту Івано-Франківського навчально-наукового інституту менеджменту Тернопільського національного економічного університету.

Наукові інтереси:

- управління рекреаційною сферою;

- маркетинг та маркетингові стратегії розвитку господарства.

Стаття надійшла до редакції 23.07.2020. 